\title{
Fruit rot of olive (Olea europaea) caused by Truncatella angustata
}

\author{
Arzanlou $\mathbf{M}^{1 *}$, Torbati $\mathbf{M}^{2}$ and Jafary $\mathbf{H}^{3}$ \\ ${ }^{1}$ Assistant Professor of Plant Pathology and Mycology, Plant Protection Department, Faculty of Agriculture, University \\ of Tabriz, PO Box: 5166614766, Iran. \\ ${ }^{2}$ MSc Student of Plant Pathology, Plant Protection Department, Faculty of Agriculture, University of Tabriz, PO Box: \\ 5166614766, Iran. \\ ${ }^{3}$ Agricultural and Natural Resources Research Center of Zanjan Province, Zanjan, Iran, PO Box:45195-1474
}

Arzanlou M, Torbati M, Jafary H 2012 - Fruit rot of olive (Olea europaea) caused by Truncatella angustata. Plant Pathology \& Quarantine 2(2), 117-123, doi 10.5943/ppq/2/2/4

Fruit rot is one of the most common diseases of olive in Iran. In a survey on the causal agents of olive fruit rot in Tarom region (Zanjan Province, Iran), olive fruits with anthracnose symptoms were collected from olive orchards. Isolation was made using routine plant pathology methods. The causal agent of the disease was identified as Truncatella angustata based on morphological and cultural characteristics. The identity of the species was further confirmed by sequence data of ITSrDNA region. Pathogenicity tests performed on olive fruits led to the same symptoms as observed in the field conditions. To the best of our knowledge this is first report on occurrence of T. angustata on $O$. europaea in any part of the world and is first record for the genus Truncatella in Iran.

Key words - anthracnose - fruit rot - ITS - pathogenicity

\section{Article Information}

Received 22 June 2012

Accepted 18 July 2012

Published online 5 September 2012

*Corresponding author: Mahdi Arzanlou - e-mail - Arzanlou@ @otmail.com

\section{Introduction}

The Iranian olive industry is a relatively small farming business with approximately 80000 hectares distributed throughout northern half of the country (FAO 2012). In recent years there has been growing interest in the cultivation of olive in Iran as a major source for vegetable oil; such that current trends are for acreage increases and planting of new varieties in different parts the country (Sadeghi 2002). There are several biotic and abiotic limiting factors for olive production in the world as well as Iran (Lazzizera et al. 2008, Moral et al. 2009). Fungal diseases represent the main constrains for olive production in Iran, attacking underground and above ground parts of olive trees including root system, trunk, stem, leaf and fruit. Several fungal diseases have been reported on olive from Iran including, Verticillium vascular wilt, peacock eyespot olive and fruit rot diseases (Ershad
2009). Fruit rot is one of the widespread diseases on olive in Iran, which reduces the quality and quantity of the product through direct loss of rotted fruits, reduced commercial value of table olives and reduced quality of the oil due to fungal infections (Lazzizera et al. 2008). Wide arrays of fungal groups have been reported to cause fruit rot on olive including Colletotrichum acutatum J.H. Simmonds, $C$. gloeosporioides (Penz.) Penz. \& Sacc., Botryosphaeria dothidea (Moug.) Cesati \& De Notaris, Neofusicoccum luteum (Pennycook \& Samuels) Crous, Slippers \& A.J.L. Phillips, Pseudocercospora cladosporioides (Sacc.) U. Braun and Camarosporium dalmaticcum (Thüm.) Zachos \& Tzav.-Klon. (Avila et al. 2005, Athar 2005, Chattaoui et al. 2011, Moral et al. 2006, 2009). Most fungal species causing fruit rot of olive are common saprophytes or secondary invaders normally penetrating through injuries made by biotic or abiotic 


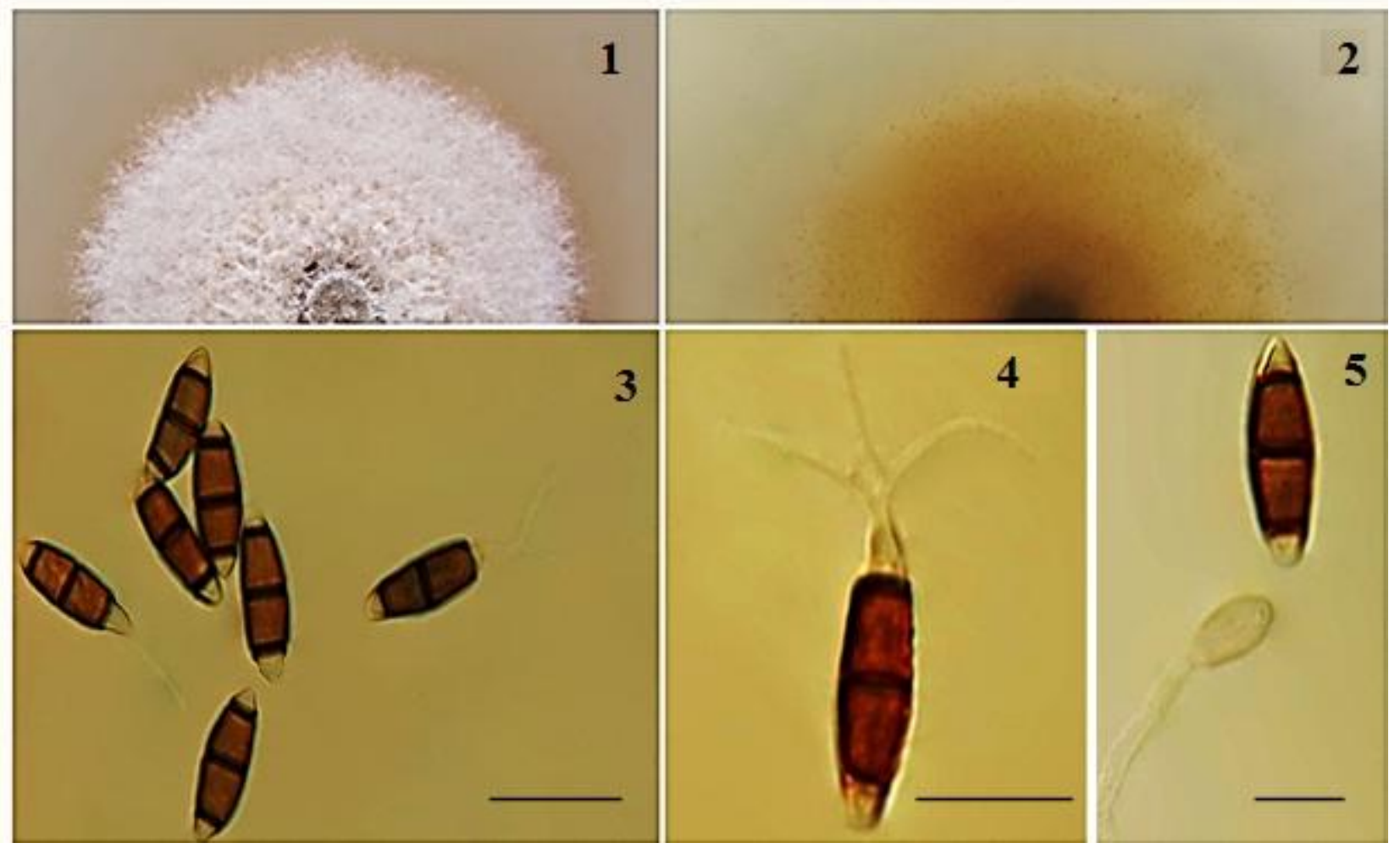

Figs 1-4 - Truncatella angustata. 1-2 7-day-old colony on PDA (1: above, 2: reverse). 3-4 Conidia with apical appendages. 5 Annellidic conidiogenous cell. - Bars $=10 \mu \mathrm{m}$.

factors (Lazzizera et al. 2008). In the present paper we report occurrence of a new fruit rot disease on olive in Iran.

\section{Methods}

\section{Isolates and morphology}

Olive fruits with fruit rot symptoms were collected from olive orchards in the Tarom region in Zanjan Province. Isolation was made from the symptomatic tissues. For this propose, small pieces approximately $0.5 \times$ $0.5 \times 0.5 \mathrm{~cm}$ were cut from the margins of infected fruit tissues and surface-sterilized for 15-20 sec in 70\% ethanol, rinsed with sterile water three times, dried on sterile filter paper and transferred to potato dextrose agar (PDA, Fluka, Hamburg, Germany) plate supplemented with $100 \mathrm{mg} / \mathrm{L}$ streptomycin sulphate and 100 $\mathrm{mg} / \mathrm{L}$ ampicillin. Single spore cultures were established from the sporulating fungal colonies according to the protocol of Bakhshi et al. (2011). Briefly, under a stereomicroscope, the tip of a wetted sterile inoculation needle was touched to conidial mass in an acervulus and suspended in plates containing $10 \mathrm{ml}$ sterile water (supplemented with streptomycin sulfate, $100 \mathrm{mg} / \mathrm{l})$. The suspension was then evenly spread over the surface of a PDA plate and the plates were kept in an oblique position overnight. The plates were then checked under the stereomicroscope and germinated conidia were transferred to new PDA plates. Single-spore cultures were preserved on PDA in $2 \mathrm{ml}$ microtube slants at 4 ${ }^{\circ} \mathrm{C}$ in the Culture Collection of Tabriz University (CCTU). Morphological characteristics were examined based on both natural substrate and single-spore cultures. Cultural and microscopic features were studied on PDA culture media (Espinoza et al. 2008). Colony morphology including colour, shape, and growth rate was determined after 7 days of incubation on PDA at $25{ }^{\circ} \mathrm{C}$ in darkness. Microscopic characters were studied using a smash mount technique with sterile distilled water as explained by Arzanlou et al. (2007). Dimension of microscopic structures were calculated based on 30 measurements for conidia morphology (shape, colour, and cell number), size (length and width), and the presence and size of apical and basal appendages where possible. 


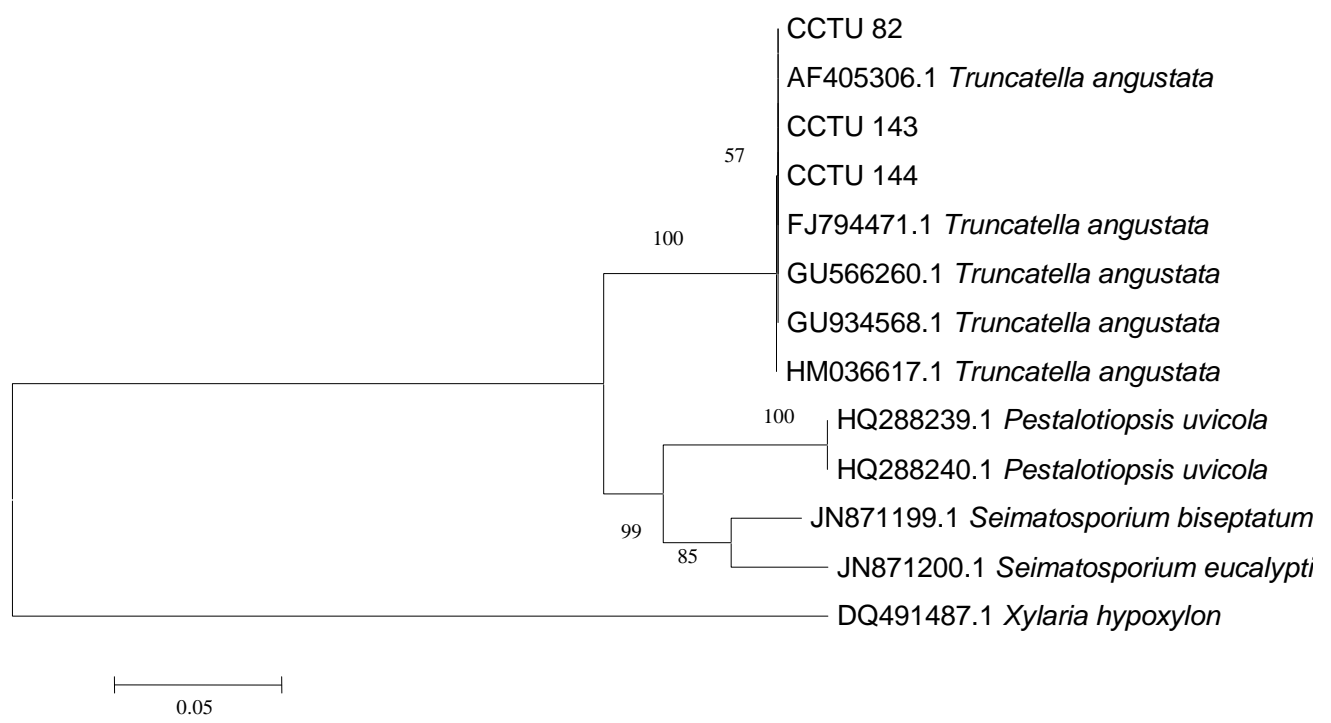

Fig. 5 - A neighbor-joining phylogenetic trees obtained from the ITS regions and 5.8S rDNA sequence data. Bootstrap support values from 1000 replicates are indicated on the nodes. The tree was rooted to Xylaria hypoxylon. The scale bar indicates 0.05 substitutions per site.

\section{Pathogenicity test}

Koch's postulates were performed on surface-sterilized healthy fruits (cultivar Zard). For this purpose, single-spore cultures were grown on PDA plates for a week to give abundant sporulation; a spore suspension with a final concentration of $10^{6}$ conidia in $1 \mathrm{ml}$ distilled water was prepared. Fresh olive fruits were dipped in $70 \%$ ethanol for $20-30 \mathrm{sec}$ and rinsed three times in sterilized water. Fruits were then dipped in the spore suspension and placed in sterilized Petri dishes containing sterilized filter paper (Watman No. 2). The filter paper was kept wet during the experiment. For the controls, fruits were dipped in sterilized distilled water. The experiment was carried out by using two fungal isolates and ten replicates (5 Petri dishes, each containing 2 fruits). Petri dishes were incubated on the lab bench under daylight regime, for 6 days until symptoms appeared.

\section{DNA phylogeny}

DNA was extracted from 8-day-old cultures grown on PDA, using the protocol of Moller et al. (1992). The primer set V9G (Vilgalys \& Hester 1990) and ITS4 (White et al. 1990) were used to amplify the 3' end of the 18S rRNA gene, ITS1, 5.8S rDNA, ITS2 and the 5' end of 28S rRNA gene regions. PCR was performed on a GeneAmp PCR System 9700
(Applied Biosystems, Foster City, CA). The thermal cycling condition consisted of an initial denaturation at $95^{\circ} \mathrm{C}$ for $5 \mathrm{~min}$, followed by 40 cycles of $30 \mathrm{~s}$ at $94^{\circ} \mathrm{C}, 30 \mathrm{~s}$ at $52^{\circ} \mathrm{C}$ and $1 \mathrm{~min}$ at $72^{\circ} \mathrm{C}$, followed by a final extension cycle at $72^{\circ} \mathrm{C}$ for $7 \mathrm{~min}$. The reaction mixture contained 1X PCR buffer, $1 \mathrm{mM} \mathrm{MgCl} 2,60 \mu$ of $1 \mathrm{mM}$ dNTPs, $0.2 \mathrm{pM}$ of each primer, $0.5 \mathrm{U}$ of Taq polymerase, $0.5 \mu \mathrm{l}$ DSMO, and 10-15 ng of fungal genomic DNA. The final reaction volume was adjusted to $12.5 \mu \mathrm{l}$ by adding sterile distilled water. Amplicons were sequenced using BigDye Terminator v3.1 (Applied Biosystems, Foster City, CA) Cycle Sequencing Kit according to the recommendation of the seller and analyzed on an ABI Prism 3700 (Applied Biosystems, Foster City, CA). Raw sequence files were edited by using SeqMan ${ }^{\text {TMII }}$ (DNASTAR, Madison, Wisconsin, USA) and a consensus sequence was generated for each of the sequences. Megablast search option at NCBI's GenBank nucleotide database was used to search for sequence similarity. Sequences with high similarity were obtained from GenBank and aligned together with the sequence obtained in this study. Sequence alignment was carried out by using ClustalW algorithm implemented in MEGA 5 (Tamura et al. 2011). Phylogentic analysis was performed using Neighbor-joining method (kimura-2 as 

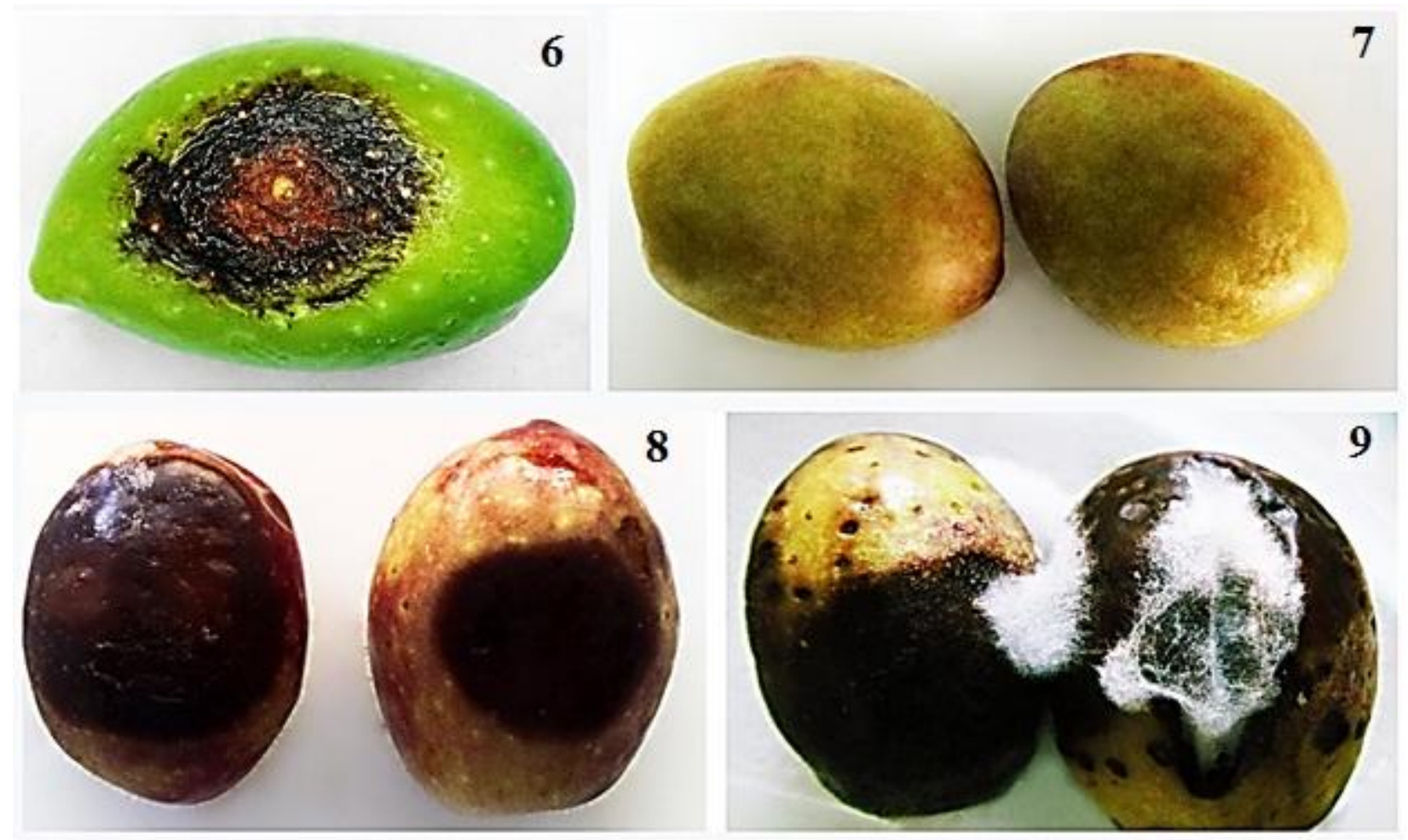

Figs 6-9 - Disease symptoms and pathogenicity test. 6 Symptomatic fruit of olive (cultivar Mary) naturally infected with $T$. angustata. 7 Control fruits (cultivar Zard) did not develop any symptoms. 8-9 Symptoms developed on in vitro inoculated olive fruits, 7 days after inoculation.

substitution model; gaps treatment as pairwise deletion). Transitions and transversions (with the equal ratio) were included in the analysis. The bootstrap analysis was performed by 10000 replicates. The phylogenetic tree was rooted to Xylaria hypoxylon (GenBank accession number DQ491 478).

\section{Results}

\section{Morphological and cultural features}

Fungal isolates were identified as Truncatella angustata (Pers.) S. Hughes based on morphological examination of pure cultures in laboratory conditions.

Disease symptoms on olive fruits: infected fruit had small, water soaked, sunken, circular spots, which became dark brown or blackish with age, resembling anthracnose disease symptoms. Fungal structures were not observed on naturally infected fruits. In culture: on PDA colonies were rather fast growing, attaining $40 \mathrm{~mm}$ diam after $7 \mathrm{~d}$ at $25^{\circ} \mathrm{C}$. Cultures developed dull white to brown, cottony colonies with black acervuli (about $500-1000 \mu \mathrm{m}$ diam), mainly in the center of the
PDA plates after $7 \mathrm{~d}$. Conidiophores hyaline, 24.5-26 × 2-4.5 $\mu \mathrm{m}$; conidiogenous cells annellidic, hyaline, integrated, smooth, cylindrical; conidia fusiform, straight 18-20 $\times$ 7-8 $\mu \mathrm{m}$, with 3 transverse septa, median cells dark brown, 12-14.5 $\mu \mathrm{m}$ long, apical and basal cells subhyaline; basal appendage absent, apical appendages variable and often branched, single or 2-3. Apical appendages were not observed in some of the conidia (Figs 1-4). The morphology of our isolates was in full agreement with the description for Truncatella angustata (Sutton 1980).

\section{DNA phylogeny}

Phylogeny inferred using the sequence data of ITS region from the isolates obtained in this study (CCTU 82, 143, 144) with other known isolates of $T$. angustata and other pestalotioid fungi from GenBank clustered our isolates with $T$. angustata (100 percent bootstrap support value) (Fig. 5). One of the sequences generated in this study was deposited to GenBank with GenBank Accession No. JX390614). 


\section{Pathogenicity test}

Pathogenicity tests performed on healthy olive fruits led to the same symptoms as observed in field conditions. Lesions on fruits became visible within $7 \mathrm{~d}$ after inoculation. Water soaked and dark brown spots appeared on the infected fruits. Controls did not develop any disease symptom. The same fungus was recovered from the inoculated material (Figs 6-9).

\section{Discussion}

The causal agent was identified as a member of the genus Truncatella Steyaert based on morphological criteria of conidia including four-cell conidia, straight to slightly curved, with hyaline apical and basal cells and two brown to dark brown, thick-walled median cells. Basal appendages were absent, apical appendages hyaline, more than one, variable in size, with dichotomous branches. The morphological description of Truncatella isolates from olive fruits was in full agreement with the description for T. angustata. (Sutton 1980, Espinoza et al. 2008). Phylogenetic analysis carried out in this study further confirmed the identity of our isolates as $T$. angustata. Olive isolates clustered together with the other isolates from GenBank with 100 percent bootstrap value.

The results of pathogenicity tests revealed T. angustata to be pathogenic on olive fruits. T. angustata has been reported to cause leaf spot on Leucospermum cordifolium and dog rose (Taylor et al. 2001, Eken et al 2009), core rot in apple (Hu et al. 1996), canker and twig dieback on Vaccinium spp. and grapevine (Espinoza et al. 2008, Úrbez-Torres et al. 2009), but only the fruit rot phase was observed in our work. In this study we did not test pathogenicity of T. angustata on olive trees to determine if this species is pathogenic on olive leaves and stems as well.

The genus Truncatella represents a well known plant pathogen, encompassing some 23 species (Crous et al. 2004). Some of the species in this genus are endophytic, colonizing plant tissues without causing visible symptoms, while others are known pathogens on a wide array of plants.

The genus Truncatella belongs to pestalotioid fungi (Lee et al. 2006). In the past, taxonomy of pestalotioids such as Bartalinia Tassi, Monochaetia (Sacc.) Allesch., Pestalotia De Not., Pestalotiopsis Steyaert, Sarcostroma Cooke, Seimatosporium Corda, Truncatella have mainly relied on morphological criteria of conidia (septation, lack or presence/ shape and branching pattern of appendages, pigmentation), which have proven to be troublesome (Jeewon et al. 2002, 2003, 2004, Kang et al. 1998, 1999, Barber et al. 2011). The morphological criteria used for the delineation of pestalotioid fungi are insufficient and overlap among different genera (Lee et al. 2006, Barber et al. 2011). With the aid of DNA sequence data, taxonomy of pestalotioid fungi has undergone drastic revision (Jeewon et al. 2002, 2003, 2004, Kang et al. 1998, 1999, Lee et al. 2006) and now the boundaries of the genera are more clear (Lee et al. 2006, Tanaka et al. 2011).

Very little is known on the biodiversity of pestalotioid fungi of Iran and there is no report of Truncatella species from Iran as well (Ershad 2009). We did not find any report on the occurrence of a Truncatella on olive anywhere in the world, and this paper reports $T$. angustata as a new pathogen on olive and first record for the genus Truncatella in Iran.

\section{Acknowledgements}

The authors would like to thank the Research Deputy of the University of Tabriz and the Studienstiftung Mykologie for financial support.

\section{References}

Arzanlou M, Groenewald JZ, Gams W, Braun U, Shin HD, Crous PW. 2007 Phylogenetic and morphotaxonomic revision of Ramichloridium and allied genera. Studies in Mycology 58, 57-93.

Avila A, Groenewald JZ, Trapero A, Crous PW. 2005 - Characterisation and epitypification of Pseudocercospora cladosporioides, the causal organism of Cercospora leaf spot of olives. Mycological Research 109, 881-888.

Athar M. 2005 - Infestation of olive fruit fly, Bactrocera oleae, in California and taxonomy of its host trees. Agriculturae Conspectus Scientificus 70, 135-138. 
Barber PA, Crous PW, Groenewald JZ, Pascoe IG, Keane P. 2011 - Reassessing Vermisporium (Amphisphaeriaceae), a genus of foliar pathogens of eucalypts. Persoonia 27, 90-118.

Chattaoui M, Rhouma A, Krid S, Triki MA, Moral J, Massalem M, Trapero A. 2011First report of fruit rot of olive caused by Botryosphaeria dothidea in Tunisia. Plant Disease 95, 770.

Crous PW, Gams W, Stalpers JA, Robert V, Stegehuis G. 2004 - MycoBank: an online initiative to launch mycology into the 21st century. Studies in Mycology 50, 19-22.

Eken C, Spanbayev A, Tulegenova Z, Abiev S. 2009 - First report of Truncatella angustata causing leaf spot on Rosa canina in Kazakhstan. Australasian Plant Disease Notes 4, 44-45.

Ershad D, 2009 - Fungi of Iran. 3rd edition, Iranian Research Institution of Plant Protection, $531 \mathrm{p}$.

Espinoza JG, Briceño EX, Keith LM, Latorre BA. 2008 - Canker and twig dieback of blueberry caused by Pestalotiopsis spp. and a Truncatella sp. in Chile. Plant Disease 92, 1407-1414.

FAO (Food and Agriculture Organization of the United Nations). 2012 - FAO Statistical Databases. http://www.fao.org/.

Hu LP, Ma CH, Yang GM, Tan WJ. 1996 Studies on the causal agent of apple mouldy core and core rot. Journal of Fruit Science 13, 157-161.

Jeewon R, Liew ECY, Hyde KD. 2002 Phylogenetic relationships of Pestalotiopsis and allied genera inferred from ribosomal DNA sequences and morphological characters. Molecular Phylogenetics and Evolution 25, 378-392.

Jeewon R, Liew ECY, Simpson JA, Hodgkiss IJ, Hyde KD. 2003 - Phylogenetic significance of morphological characters in the taxonomy of Pestalotiopsis species. Molecular Phylogenetics and Evolution 27, 372-383.

Jeewon R, Liew ECY, Hyde KD. 2004 Phylogenetic evaluation of species nomenclature of Pestalotiopsis in relation to host association. Fungal Diversity 17,
$39-55$.

Kang JC, Kong RYC, Hyde KD. 1998 Studies on the Amphisphaeriales. 1. Amphisphaeriaceae (sensu stricto) and its phylogenetic relationships inferred from 5.8 S rDNA and ITS2 sequences. Fungal Diversity 1, 147-157.

Kang JC, Hyde KD, Kong RYC. 1999 Studies on Amphisphaeriales: the Amphisphaeriaceae (sensu stricto). Mycological Research 103, 53-64.

Lazzizera C, Frisullo S, Alves A, Phillips AJL. 2008 - Morphology, phylogeny and pathogenicity of Botryosphaeria and Neofusicoccum species associated with drupe rot of olives in southern Italy. Plant Pathology 57, 948-956.

Lee S, Crous PW, Wingfield MJ. 2006 Pestalotioid fungi from Restionaceae in the Cape Floral Kingdom. Studies in Mycology 55, 175-187.

Moller EM, Bahnweg G, Geiger HH. 1992 - A simple and efficient protocol for isolation of high molecular weight DNA from filamentous fungi, fruit bodies, and infected plant tissues. Nuclear Acid Research 20, 6115-6116.

Moral J, De La Rosa R, Leon L, Barranco D, Michailides TJ, Trapero A. 2006 - High susceptibility of olive cultivar FS-17 to Alternaria alternata in Southern Spain. Plant Disease 92, 1252.

Moral J, Oliveira R, Trapero A. 2009 Elucidation of the disease cycle of olive anthracnose caused by Colletotrichum acutatum. Phytopathology 99, 548-556.

Sadeghi H. 2002 - Olive Production and Management. The Research, Training and Extension Organization of Agriculture, Agricultural Training Publication, Karaj, Iran, 413 p.

Sutton BC. 1980 - The Coelomycetes. Fungi imperfecti with pycnidia, acervuli and stromata. Commonwealth Mycological Institute, Kew.

Tamura K, Nei M, Kumar S. 2011 - MEGA5: Molecular Evolutionary Genetics Analysis using Maximum Likelihood, Evolutionary Distance, and Maximum Parsimony Methods. Molecular Biology and Evolution 28, 2731-2739.

Tanaka K, Endo M, Hirayama K, Okane I, 
Hosoya T, Sato T. 2011 - Phylogeny of Discosia and Seimatosporium, and introduction of Adisciso and Immersidiscosia genera nova. Persoonia 26, 85-98.

Taylor JE, Crous PW, Swart L. 2001Foliicolous and caulicolous fungi associated with Proteaceae cultivated in California. Mycotaxon 78, 75-103.

Urbez-Torres JR, Adams P, Kamas J, Gubler WD. 2009 - Identification, incidence, and pathogenicity of fungal species associated with grapevine dieback in Texas. American Journal of Enology and
Viticulture 60, 497-507.

Vilgalys R, Hester M. 1990 - Rapid genetic identification and mapping of enzymatically amplified ribosomal DNA from several Cryptococcus species. Journal of Bacteriology 172, 4238-4246.

White TJ, Bruns TD, Lee SB, Taylor JW. 1990 - Amplification and sequencing of fungal ribosomal RNA genes for phylogenetics. In: PCR-Protocols and Applications - A Laboratory Manual (eds N Innis, D Gelfand, J Sninsky, TC White). Academic Press, New York 315-322. 